\title{
The legal aspect of security over future receivables in Japan and suggestions for Vietnam
}

\author{
Lien Dang Phuoc Hai*
}

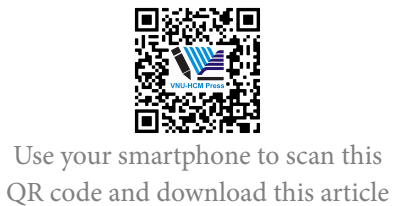

\begin{abstract}
Enabling the use of future receivables as collateral to access to credit is highly economically meaningful, as its development is for one thing to assist businesses and individuals to access the capital easily with movable assets to be accrued in the future, and for another thing to encourage lending by reducing the financial vulnerability of lenders. In Vietnam, the recognition of future objects as a form of property eligible to be used as collateral since the 2005 Civil Code has had positive impacts on business financing. However, the term "future objects" does not explicitly cover all types of assets to be formed in the future such as future property rights not categorized as eligible collaterals. This shortcoming later has been revised and supplemented under Decree 163/2006/ND-CP, amended by Decree 11/2012/ ND-CP (Collectively Decree 163) which permits the creation of security over both existing and future receivables. The 2005 Civil Code has been replaced by the 2015 Civil Code, and it is necessary to revise or replace Decree 163 to reflect the changes in the Civil Code and the new practice. Vietnamese Government has been collecting comments for a draft decree on security measures to replace Decree 163 , and this article aims to analyze the legal schemes in the former and current Civil Code regarding the use of future receivables as security for performance obligations in comparison with the regulations of Japanese laws on the same matters. The author will try to provide suggestions drawing from Japanese lawmaking for reforming Vietnamese statutory.

Key words: security interest, future receivables, collateral, security assignment, validity, security measures
\end{abstract}

Law Faculty, University of Economics and Law, VNU-HCM

\section{Correspondence}

Lien Dang Phuoc Hai, Law Faculty, University of Economics and Law, VNU-HCM

Email: haildp@uel.edu.vn

History

- Received: 25/8/2019

- Accepted: 10/12/2019

- Published: 11/9/2020

DOI : 10.32508/stdjelm.v4i3.633

\section{Check for updates}

\section{Copyright}

(c) VNU-HCM Press. This is an openaccess article distributed under the terms of the Creative Commons Attribution 4.0 International license.

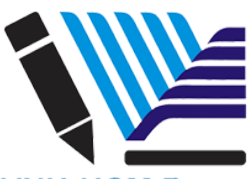

VNU-HCM Press goods, or services. ${ }^{\text {a }}$ Receivables, as an asset, can be assigned and utilized as collateral to secure the performance of obligations. Receivables may be accrued receivables or future receivables. An accrued receivable (existing receivable) is a receivable that arises upon or before the conclusion of the security agreement and a future receivable is a receivable that arises after the conclusion of the security agreement. Future receivables, if utilized as collateral, bring many benefits for debtors as debtors may take advantage of their future supply contracts, lease contracts, service contracts, etc. to access credit easily. In practice, future receivables are still used by businesses as collateral for secured loans. For example, in financing for commercial housing projects, banks often accept investor's collateral that are future receivables arising out of selling eligible housing. ${ }^{\mathrm{b}}$ the risk borne by lendy to re the thanks to realization of collateral in case of default. Among movable properties, receivables undoubtedly become more important, particularly for small companies, as they usually cover a high proportion of a company's assets. In a company, receivables mean claims held against customers and others for money, a Joel G. Siegel, Jae K. Shim. Dictionary of Accounting Terms. Barron's Educational Series, Inc; 2005. 682.

${ }^{b}$ Vinh TQ, Giang BD. Suggestions for the draft decree on secured transactions: a viewpoint from secured credit practice (Một số góp ý cho dự thảo nghị định về giao dịch bảo đảm: góc nhìn từ thực tiễn cấp tín dụng có bảo đảm). Banking Review 2016. 21. 
In Vietnam, receivables, whether existing or future, are regarded as a form of debt-claims. ${ }^{c}$ Therefore, the statutory framework applicable to debt-claims is technically the same as that of receivables. Under the 2005 Civil Code, the debt-claim is regarded as a property right that can be utilized to secure performance obligations. $^{\mathrm{d}}$ Notably, this Code only enabled entities to use future objects to secure the performance of the obligation. ${ }^{\text {e }}$ In other words, other types of future assets, such as the future property right does not fall into the scope of eligible collateral. This limitation later has been supplemented by Decree 163, which permits the creation of mortgage over debt-claims, including existing or future debt-claims. Despite the efforts of lawmakers, the legal framework for the security over future property, particularly future receivable, provided under Decree 163 has not been as effective as expected to resolve the shortcomings arising in practice. A number of underlying issues remain untouched by Decree 163, thereby causing a lot of difficulties for businesses in the course of implementation. In Japan, although the security interest in future receivables was not officially recognized in Act No. 89 of dated April 27, 1896 (the Japanese Civil Code) and it was left to the interpretation of the legislation, a judicial precedent recognizing transfers of future receivables in 1999 marked a turning point in the secured transactions area. ${ }^{\mathrm{f}}$ Until recently, the Act to Partially Amend the Japanese Civil Code, which will come into effect on April 1, 2020, expressly provides that future receivables can be pledged or transferred. ${ }^{g}$ The Japanese and Vietnamese legal regulations on securitization of future receivables share some similarities, though there are also divergences such as third party effectiveness, priority rule among competing claims, and recognition of security made notwithstanding an anti-security clause.

\section{OVERVIEWS OF SECURITY INTERESTS OVER FUTURE RECEIVABLES IN JAPAN}

The prevailing Japanese Civil Code provides that the pledge over receivables shall take effect by the delivery

\footnotetext{
${ }^{c}$ Under clause 1.1, point d, Circular 04 dated 17 May 2007 of the Ministry of Justice, a transfer contract of the debt-claims includes debts arising from contracts, for example, loan contracts, lease contracts, sales contracts, services contracts, and other legal bases.

d See Article 322.1 of the 2005 Civil Code.

${ }^{\text {e}}$ See Article 320 of the 2005 Civil Code.

fS Supreme Court, 29 Jan. 1999, Minshu 53-1-151.

${ }^{\mathrm{g}}$ See Article 364 and Article 466 para. 6 of the Act to Partially Amend the Japanese Civil Code.
}

of the instrument evidencing it is required for its assignment. ${ }^{\text {h }}$ Nevertheless, in the case of future receivables, which do not accrue at the time of the transaction, obligors can not use it for the pledge as the requirement for delivery of such instrument. The same with a mortgage, although the possession of the property is not transferred to the obligee, ${ }^{i}$ the Japanese Civil Code only limits the object of the hypothec to ownership of immovable and superficies and emphyteutic over land. ${ }^{j}$ In other words, the hypothec over the movable is not acknowledged by the Code, except for certain limited movables. ${ }^{\mathrm{k}}$

Having said that, there are two additional types of securities so-called atypical real security, including title transfer security and preliminary registration security $^{1}$. These security interests have developed out of business practice and are recognized as security by both case law and academic views to fill the gaps in the Japanese Civil Code regarding the security over movables which allows a debtor to use the property until he repays the debt ${ }^{2}$. The title transfer security (security assignment) is a type of a mortgage arrangement, in which the ownership of secured property is transferred directly to the lender until the debt is discharged in full, but the possession of the property to use the secured assets remains with debtors ${ }^{3}{ }^{1}$. Given that, the security over future receivables, which has by nature not formed yet at the time of the transaction, may be created in form of security assignment because it is not possible to transfer the possession of the collateral to the obligee. ${ }^{\mathrm{m}}$ On the other hand, legal

\footnotetext{
${ }^{\mathrm{h}}$ See Article 363 of the Japanese Civil Code.

${ }^{\text {i }}$ See Article 369 of the Japanese Civil Code.

jAccording to H. Oda, the reason for this limitation is because there is no way to publicize the existence of a mortgage over movables, and in case that the mortgages over movables were allowed, the interest of those who purchase movables could be seriously harmed. See Oda H. Japanese Law. Oxford: Oxford University Press. 3ed; 2009; p. 176.

${ }^{\mathrm{k}}$ In fact, at present, although there are certain types of movables can be mortgaged according to the specific laws such as the Law in Hypothec over Automobiles, and the Law on Hypothec over Factories, future receivables still cannot be mortgaged under the prevailing Japanese Civil Code.

${ }^{1}$ In Vietnam, although there is the controversy of assignment as a form of security, the judicial precedents are considered assignment is not a form of security assignment subject to the current law and consequently, the assignee would not be viewed as a secured creditor. For more information, see Dai DV. Law of Obligations and Security Obligation Performance Security: Judgments With Comments: Chapter 2 (Luật Nghĩa Vụ Và Bảo Đảm Thực Hiện Nghĩa Vụ Việt Nam: Bản Án Và Bình Luận Bản Án: Tập 2). Hong Duc Publisher; 2017; p. 872-886.

${ }^{\mathrm{m}}$ In the Judgment dated January 26, 1996, the Osaka High Court allowed the obligor to use the collective receivables consisting of present and future receivables to hypothec for the creditors over the obligation. This case again asserted that the security over future receivables may be created by the security assignment. Case to seek receivables to be assigned. $54 \mathrm{Minshu}, 4,1562$ (Osaka High Court,
} 26 Jan. 1996, Minshu 54-4-1562). 
normative documents, that is, the Act on Special Provisions, etc. of the Civil Code Concerning the Perfection Requirements for the Assignment of Claims conforms with the judicial precedent by recognizing the transfer of future receivables and provides the registration of the transfer of receivables as a kind of perfection requirement.

Until recently, the Act to Partially Amend the Japanese Civil Code allows the future receivables to be pledged or assigned in the same way as existing receivables.

\section{CURRENT LEGAL FRAMEWORK FOR TAKING SECURITY OVER FUTURE RECEIVABLES IN JAPAN}

\section{The identification requirement}

The future property is usually regarded as uncertainty and high risk in practice because it is by nature a property that has not existed yet at the time of transaction. That explains why the future property, to become collateral, often needs numerous documents proving its future appearance and its future ownership by the securing party.

In Japan, security assignments over future receivables have been recognized since the Japanese Supreme Court's Judgement on January 29, 1999. In this case where A-a physician entered into a contract with YLeasing Company, of which A transferred to $\mathrm{Y}$ his right to claim medical fees owed to A from B- the Social Insurance Medical Fee Payment Fund for eight years and three months. Notice of this assignment was given to B by a deed bearing fixed date. Nevertheless, the validity of this contract was later challenged by the $\mathrm{X}$ - the State of Japan for the reason that part of the contract pertaining to those claims to payment of medical fees was to fall due more than one year after the transfer started. However, the Supreme Court dismissed a one-year limitation and upheld the eight-year validity of the assignment of the future assets as agreed by the parties, starting from the execution of such assignment. It is noted that such assignment is only valid under the condition that it adequately defined the starting and ending of the term under which future receivables would be assigned ${ }^{4}$. To some extent, this judicial precedent has laid down the essential requirements for a future receivable to be specified, for example, by the reasons for and the time of their accrual or the amount subject to the assignment. If several receivables to be assigned that emerge or accrue within a stipulated future period, the receivables to be assigned are identified by providing for the commencement and expiration of the accrual of receivables. ${ }^{\mathrm{n}}$ In addition, the Supreme Court

\footnotetext{
${ }^{\text {n }}$ Supreme Court, 29 Jan. 1999, Minshu 53-1-151.
}

also ruled that the validity of the future receivable will not be affected by the low likelihood of the accrual of a receivable. ${ }^{\circ}$ Nevertheless, the judicial precedent also implied that if a security agreement is determined to be against public policy, the effectiveness of part or all would be negated. More specifically, if a security agreement permits an assignment that would socially be considered a greatly unfair detriment to the business activities of the obligor, and the transfer of the future receivables, if approved, would entitle the transferee an unfair preference over other creditors of the obligor. $^{\mathrm{p}}$

\section{Ban on non-assignment or security clause}

In practice, parties in the receivable contract, particularly large companies with sufficient credit strength do not want to use rights under the contract to transfer or to be secured for other obligations. Therefore, the contracting parties usually put a non-assignment and security clause which prohibits the security of the contract right, such as rights to payment, for the other obligation as the obligor may not wish to change obligee.

In Japan, the Civil Code recognizes the validity of the anti-assignment clause, provided, however, that the anti-assignment will be ineffective against a third party assignee who did not know of the existence of the anti-assignment clause. ${ }^{\mathrm{q}}$ This approach seems unreasonable, according to T. Uchida, as "an agreement between the obligee and obligor can deprive a right of its alienability" ${ }^{5}$. After the Act to Partially Amend the Japanese Civil Code, the assignment of a receivable will be effective notwithstanding any agreements that prohibit or restrict a transfer of receivables. ${ }^{r}$ The preclusion of contractual prohibitions aims to help businesses raise funds by securing receivables as collateral in a lending arrangement. Besides, to protect the obligor's interest in not permitting any third party to become a contracting party, the Amendment grants the obligor the right to not perform the

${ }^{\circ}$ This principle later was abided by the Osaka High Court in the Judgment of 26 January 1996. The Osaka High Court ruled that the amount of receivables secured by the Promise may increase or decrease in the future but it will be finally determined at the time when its intention to cause the promise to be fulfilled is declared. Therefore, the fact that the amount of receivables was not determined at the time when the Promise was made does not affect the validity of the Promise, as the judgment states. See Osaka High Court, 26 Jan. 1996, Minshu 54-4-1562.

PSupreme Court, 29 Jan. 1999, Minshu 53-1-151.

${ }^{\mathrm{q}}$ Article 466 para. 2 of the Japanese Civil Code

${ }^{\mathrm{r}}$ Article 466-6 of the Act to Partially Amend the Japanese Civil Code provides that a claim may be assigned; provided, however, that this does not apply if its nature does not permit the assignment. Even if a party to a claim manifests the intention to prohibit or restrict the assignment of the claim, the validity of the assignment of the claim is not impaired. 
payment obligation to a third party such as the assignee that was aware or fail to become aware due to gross negligence, of the manifestation of intention to restrict assignment was made, and assert defences that work to extinguish the transferred receivable or claim ${ }^{6}$.

\section{The attachment and perfection}

The security over the receivable, whether existing or future, is by nature not a bilateral relation, but a trilateral legal relationship between the mortgagor, the mortgagee and the underlying debtor of the receivable. Therefore, in a security agreement, if the attachment is to some extent viewed as the moment when the security enforceable against the relevant debtors, the perfection of the security is an additional step required to be taken related to a security interest to make it effective vis-á-vis the third parties' claim to the collateral.

In Japan, security assignment over receivables, whether existing or future, shall take effect immediately from the assignment date ${ }^{4}$. Concerning assertion of the security assignment over future receivables against applicable obligors, the method is the same as would be applicable for receivables already arisen. Accordingly, to perfect the security assignment of the receivable with respect to debtors, the securing party - assignor may give notice of the security assignment to the obligor, or obtaining an acknowledgment from, each obligor. Prior to giving notice, the debtor will only pay the debt amount to the original creditors (the assignor) on the ground of receivables. The requirement to give notice to the debtor is therefore purposely to make sure that the debtor will know whom to pay to. In Japan, the assignee is not entitled to give notice of the security assignment to the debtor (Article 467 para. 1 of the Japanese Civil Code). In other words, the assignee's notice shall be ineffective. For instance, in the case where the assignor goes bankrupt before giving notice of the assignment to the debtor, subsequently, the assignee cannot perfect the assignment against the debtor. ${ }^{\mathrm{s}}$

Under the legal landscape of Japan, the requirements for perfection against the other parties other than obligors seem stricter than the perfection against applicable debtors. As to the rules on perfection against

\footnotetext{
${ }^{s}$ In this case, the assignee cannot claim the debt directly against the debtor but can only participate in the distribution procedure of the bankruptcy assets as an unsecured creditor. See Woo-Jung J. The Assignment of Receivables under the Chinese Contract Law and Some Suggestions. Peking University Journal of Legal Studies 2012; 3:119.
}

the third parties (other than obligors), two systems are coexisting in Japan. The first system is similar to the French system and Article 9.1.11 of the UNIDROIT Principles, according to T. Uchida ${ }^{5}$. The assignor must use an instrument (a certificate) with a fixed date for the notices or acknowledgments. ${ }^{t}$ Normally, the notary will either stamp a date on the document or notice or acknowledgment will be sent by certified mail associated with a certificate of receipt.Because the notarization was never an essential condition for perfection in receivables, especially when the assignor needs to make the notice of the securitization too many debtors, it is very expensive and burdensome ${ }^{7}$. Thus, in 1993, the Law for Regulating Business for Specific Claims, Act No 77 of 1992 (MITI Securitization Law) was passed.

It allowed the assignor to perfect the security assignment relating to obligors and other third parties to be accomplished by the public notice in newspapers ${ }^{4}$.

The second way for the successive security assignment of future receivables, as to the third parties other than relevant debtors in the Perfection Law in 1998 required companies to file an electronic registration with the Legal Affairs Office of the Japanese government. In this context, the assignor can simply register for the securitization of assets, whether existing or future, once the securitization of assets is registered, the security assignment will perfect against the other third parties. Since the new provision is mainly designed for the business financial use ${ }^{8}$, the registration regime contemplated in the Perfect Law in 1998 was only applicable to the judicial person (Article 4 para. 1). Nevertheless, it is impossible to register for future receivables relating to unspecified debtors in the 1998 Perfection Act. Therefore, the 1998 Perfection Law was amended by the Act on Special Provisions, etc. of the Civil Code Concerning the Perfection Requirements for the Assignment of Movables and Claims in 2004 which enabled the registration of future receivables to unspecified debtors ${ }^{8}$. As such, under Japanese law, it is possible to perfect a transfer of future receivable against unspecified debtors as well as the other third parties through registration. For existing receivables, the debtor's name and address must be registered (Article 11 para. 2 of the Perfection Law), however, for future receivables, the name and address of the debtor cannot be registered as the debtor of the future receivables cannot specify at the time of registration. Instead, details of the contract upon which the future receivable will accrue

\footnotetext{
${ }^{\mathrm{t}}$ See Article 467 para. 2 of the Japanese Civil Code.
} 
must be registered to specify the contract, and the period of the accrual (a commencement and termination date $)^{9}$. ${ }^{\mathrm{u}}$ Although it is quite cumbersome for the registration of future receivables, Japanese legislators believed that the registration of such details should nonetheless be required to specify the receivables ${ }^{9} .{ }^{\mathrm{v}}$ After the effectiveness of the Act to Partially Amend the Japanese Civil Code, perfection of a pledge over future receivables will be similar to a security assignment of receivables. ${ }^{\mathrm{w}}$

\section{The enforcement of the security over future receivables}

In Japan, the security assignment, rather than pledge and hypothec, is attractive to creditors because it can help the creditor avoid the inefficient procedure for the enforcement contemplated in the Japanese Civil Code and a chance of confiscating the collateral once borrowers default ${ }^{3}$. As a general rule, future receivables may be enforced only if the securing party has become the holder of the right to collect receivables. In case that a receivable does not accrue as it was previously anticipated, the debt will be settled by way of the transferee's pursuit of the transferor for contractual liability. ${ }^{\mathrm{x}}$ For the enforcement of security interests over receivables, the step is quite simple that the secured party may directly claim against the relevant debtor of the receivables or proceed with a private aution ${ }^{10}$. y It should be noted that if the amount of debt (or the appraised amount in case of movable assets) is less than the obligation, the obligee credits the debt

\footnotetext{
"See Article 8 of the Perfection Law.

${ }^{\mathrm{v}}$ Arguably, Basic Reform Policy promulgated by Civil Code Reform Commission in 2009 suggested that Japan should merge two prevailing systems into a single registration system on the transfer of receivables to meet the demands of corporate finance with respect to the transfer of receivables. See Uchida T, Contract Law Reform in Japan and the UNIDROIT Principles. Uniform Law Review 2011; 16 (3). However, the practitioners criticize that the registration system seems impractical. In fact, it is not easy to set up a new system enables people to register their assignment of the claim due to the cost and privacy concerns. See Kamo A. Crystallization, Unification, or Differentiation? The Japanese Civil Code (Law of Obligations) Reform Commission and Basic Reform Policy (Draft Proposals). Columbia Journal of Asian Law 2010; 24 (1).

${ }^{w}$ Article 364 of the Act to Partially Amend the Japanese Civil Code provides that the creation of a pledge over a claim (including a pledge over a claim which has not yet arisen) may not be duly asserted against a third party obligor and other third parties unless notice of the creation of the pledge is given to that third party obligor in accordance with the provisions of Article 467, or unless that third party obligor gives consent to the same.

${ }^{\mathrm{x}}$ See Supreme Court, 29 Jan. 1999, Minshu 53-1-151

${ }^{y}$ Under the Act to Partially Amend the Japanese Civil Code, Article 366 provides that the creation of a pledge over a claim (including a pledge over a claim which has not yet arisen) may not be duly asserted against a third party obligor and other third parties unless notice of the creation of the pledge is given to that third party obligor in accordance with the provisions of Article 467, or unless that third party obligor gives consent to the same.
}

amount to the obligor's obligation. If the debt amount exceeds the obligation, the obligee must return the excess to the obligor. ${ }^{Z}$

\section{ANALYSIS OF THE POSSIBLE HURDLES AND SUGGESTION FOR IMPROVEMENT IN VIETNAM}

In Vietnam, receivables are viewed as a form of debtclaims, and thus, statutory framework applicable to debt-claims is technically the same as that of receivables. The mortgage over receivables, whether existing or future, shall similarly be governed by the provisions that are applied for the mortgage over debtclaims.

\section{The lack of guidance on the identification}

In Vietnam, Decree 163 and Article 295.2 of the 2015 Civil Code provide that collateral may be generally described but must be identified in security agreements. $^{\text {aa }}$ Therefore, a description of the collateral becomes one of the requirements of a valid security agreement ${ }^{11}$. It could be reasonably assumed that security agreement must identify receivables, whether existing or future, to be enforceable under the law and the security agreement can be void in case of unidentified collaterals. But for future receivables, it may be troublesome for the contracting parties to depict the collateral to identify as well as the registrars for the registration purpose because we most often than not cannot identify specific debtors. In the event of the description of the future claim is insufficient to identify, the mortgagee, as the secured party would likely suffer from the damages due to the invalidity of the mortgage agreement. From the Japanese legislation and judicial precedents, the Vietnamese law should recognize the validity of mortgages over future receivables, provided that at the time of executing the mortgage, the future receivables are identifiable. Recommended elements to identify future receivables for the contracting parties and the registration agency may include the grounds and duration of accrual of the receivables, including the starting and ending of the term under which receivables will be mortgaged.

\footnotetext{
${ }^{\mathrm{z}}$ In the past, a creditor was entitled to receive full ownership of the assets regardless of its value. Therefore, the creditor could get the ownership of the collateral even with a higher value than that of the loan. It seemed unfair to the debtors whose obligation was secure, the judgment of the Supreme Court, 25 March 1971 (minshu 25-2208) established the rule that the difference between the amount of the secured loan and the price of the property should be returned to the debtor. Oda H. Japanese Law. Oxford: Oxford University Press. 3ed; 2009. p. 178-9.

${ }^{\text {aa }}$ Previously, Article 10.2 of Decree 163 provided that the general description of collaterals would not invalidate the secured transactions. However, since the amendment of Decree 163 in 2012, this provision was removed.
} 
The requirement for the notification obligation

Under Decree 163, it is not required for either the mortgagee or mortgagor, at the time of execution the security agreement, to notify debtors of the security over a debt-claim, whether existing or future. However, it is legally required that the mortgagee supplies information on the mortgage agreement over the debt claim when so requested by the debtor, and in return, the debtor has the right to request the mortgagee to provide information on the mortgage agreement of the debt claim. If no information is provided by the mortgagee, the debtor may refuse to pay the debt to the mortgagee. As such, unless the mortgagee proactively notices debtors, there is no way for the relevant debtors to acknowledge the existence of the security over receivables, even after the future receivables has officially become the accrued receivables. Consequently, many cases where the debtor could not know to whom they should pay the debt to, and subsequently the debtor will likely discharge the amount of debt to the mortgagor, as the original creditor. For example, in the Judgment No.89/2016/KDTM-PT dated July 14, 2016, of the Hanoi High Court, the Court agrees that the debtor (Ciencol Company) did not acknowledge of the secured transaction over the receivable because of the lack of notification from the mortgagee (the SCB Bank), subsequently, the payment of the debtor (Ciencol Company) to the mortgagor (Nguyen Trai Company) is still effective. Therefore, the mortgagee could not require the debtor to repay the debt to the mortgagee ${ }^{12}$. In doing so, the mortgagee will likely suffer from being an unsecured creditor if the mortgagee does not notify the relevant debtors about the secured transaction in advance, although it is not a compulsory step under the Civil Code.

Japanese law provides that the security assignment shall be deemed as ineffective against the applicable obligor or any other third parties unless the assignor gives a notice thereof to the obligor or the obligor has acknowledged the same. ${ }^{\text {b }}$ Hence, the relevant debtors would likely know about the existence of the security interest, and thus they will not discharge the debt by paying the debt to the securing party (the assignor) upon the notification of the assignor. Having said that, this provision still cannot resolve the shortcoming arising from the practice, where the assignor does not want to notify the debtor about the security assignment because it may prejudice the securing party's

\footnotetext{
${ }^{\mathrm{bb}}$ See Article 467 para. 1 of the Japanese Civil Code.
}

reputation or creditability, and the assignee is not entitled to send the notification to the debtor. Consequently, the assignor still reserves the right to collect the debt ${ }^{13}$. To prevent such situation from occurring, the other countries experience such as France or Germany, ${ }^{c c}$ where both the assignor and the assignee can give notice of the assignment to the debtor to be perfected the secured transaction.

From the above analysis, because the mortgagee usually has a major interest in avoiding that the debtor will perform in favour of the mortgagor notwithstanding the secured transaction, they will initiate the performance of the notification. Thus, the Vietnamese law should provide the responsibility of the mortgagor to notify relevant debtors about the mortgage promptly after the time of execution of the mortgage. Also, the mortgagee may, at its discretion, notify the relevant debtor about the security over the receivables. Concerning future receivables, in the case where it is impossible to identify the specific debtors at the time of execution the mortgage, after the acquisition of the future receivables, the mortgagor shall notify the relevant debtors immediately of the secured transaction and the mortgagee also has the same right and obligation to notify relevant debtors as applicable to the existing receivables.

\section{Perfection against third parties}

Under Vietnamese law, for a mortgage over receivables, whether existing or future, to be effective viaà-vis third parties, there is no choice but to register the mortgage (Article 319.2 of the 2015 Civil Code). If a receivable is mortgaged for many obligations, the conflict of interests among the secured parties shall be settled as follows: (i) If all types of security measures are registered, the priority shall be determined subject to the order of registration of security measures. (ii) If there is no registration of the security measures, the preference shall be established subject to the order of execution of the security agreements (Article 308 of the 2015 Civil Code). Therefore, the priority shall be subject to the chronological order of registration of the mortgagee rather than the order in

${ }^{\mathrm{cc}}$ The French Civil Code provides that where, before the debtor has been given notice by the assignor or the assignee, the debtor has paid the assignor, he is lawfully discharged (Article 1691). From the German legal perspective, the Civil Code provides that if the obligee notifies the obligor that he has assigned the claim, he must allow the notified assignment to be asserted against him in relation to the obligor, even if it does not occur or is not effective. It is equivalent to notice if the obligee has issued a document relating to the assignment to the new obligee named in the document and the latter presents it to the obligor (Article 409.1). 
which the debtor receives the notification of the respective security agreements. Some argue that this approach seems ineffective and unfair as it does not consider the order of the notification to the debtor, which is regarded as a key factor to determine the priority of the security over receivables. To illustrate, where the mortgagor uses a receivable to secure two separate loans including the first one having registration of the mortgage but no notification and the later one without registration but notification to the debtor, the debtor will likely discharge the amount of debt for the second mortgagee due to lack of notification of the first mortgagee, even though the first security interest has already registered. However, under the prevailing Vietnamese law, the debtor must make payment to the first mortgagee, and, since the second mortgage is not registered, it is ineffective against the debtor and the debtor therefore need to recourse the money from the second mortgagee, probably via litigation. In this case, the interest of the debtor is seriously harmed. For this reason, there are opinions that the law should prioritize the competing claims on the basis of the chronological order of notification to the debtor, rather than the order of registration or execution of the secured transaction ${ }^{14}$.

However, the above suggestion is problematic and needs to be further discussed. Although the priority rule based on the time of notification of security agreement is widely observed in some jurisdictions such as France, Korean, and even Japan, ${ }^{\text {dd }}$ in the case of Vietnam, the priority rule should be subject to the order of registration for the secured transaction. The rationale is that it is usually not possible to identify the debtors in the security agreement until the right to payment arises, it is not practicable to request the mortgagor and mortgagee to give the notification to underlying debtors about the mortgage agreement since there is no debtor to notify. Besides, the case where the debtor discharges the debt in favour of the second unregistered (therefore invalid) mortgagee notwithstanding the first registered secured transaction can be avoided by providing under the law that either mortgagee or mortgagor must send a notification to the debtor of the secured transaction as soon as practicable. The debtor can then determine easily to whom to pay by checking the Registration Agency for Secured Transactions of the Ministry of Justice in just a few minutes. Besides, as. In such a case, the registration system, rather than notification seems effective to perfect the security transaction over third parties.

\footnotetext{
${ }^{\mathrm{dd}}$ See Article 1690 of the French Civil Code; Article 450 para. 1 of the Korean Civil Code; Article 467 of the Japanese Civil Code.
}

\section{Preclusion of non-security clause}

The 2015 Civil Code provides that a claim may be transferred to a subrogatee of the obligee as agreed, except for the case that the obligee and the obligor agree that the claim may not be transferred (Article 365.1 , point $b$ ). Though the mortgage as a security measure is not the assignment of the claim in nature, there are opinions that the said regulation will be likely applicable to the security over the receivable. In other words, the non-security clause will be valid and effective ${ }^{11}$.

This approach is quite problematic. The preclusion of contractual prohibition or restrictions of a transfer of rights, from the Japanese lawmaking experience, is to encourage more assignments of receivables in business transactions, including financing with receivables assigned as collateral ${ }^{6}$. In addition, since the nature of future receivables that is yet to arise, one issue that is likely to happen is when an antisecurity clause is effected subsequent to the security of future receivables. In this case, if we only protect the obligor by way of acknowledging the validity of the non-security clause, the mortgagee's interests will be left unprotected.

Since the 2015 Civil Code does not mention about the non-security clause, the draft decree to replace Decree 163 should provide guidance regarding the intention to prohibit the security of receivables, whether in existing or future. The suggestion is that the Vietnamese law should protect the mortgagee by recognizing the effectiveness of the mortgage agreement made in violation of a non-security clause. To be clear, the draft decree should provide that a claim (including the one that is yet to arise) can be secured partly or wholly for performance of obligations, provided, however, that this does not apply if its nature does not permit the security. Even if a party to a claim manifests the intention to prohibit or restrict the security of the claim, the validity of the security of the claim is not impaired. This approach will provide greater protection to the mortgagee as to the mortgage.

Furthermore, if the mortgagor acts contrary to its contractual duties while entering into a prohibited security agreement, it should be liable for all damages incurred by the obligor for its violation, for instance, the arising fee for transferring the money to the mortgagee in case of the enforcement of the security over future receivables.

\section{CONCLUSION}

Receivables, whether existing or future, tend to comprise a large proportion of a company's assets that can 
be utilized as meaningful collateral to access credit at affordable rates. The 2015 Civil Code fully allows the use of assets to be formed in the future to ensure the fulfilment of obligations. However, the regulatory framework concerning future receivables in Vietnam is still inadequate to deal with practical issues arising from its implementation. A reference to Japanese law can provide good consideration for improving the legal framework for securing future receivables, especially in the development of criteria to identify future receivables. Setting practical criteria to identify future receivables not only benefits for the parties in the security agreement but also assists state management to develop a comprehensive legal framework on registration of assets in the present context.

\section{COMPETING INTERESTS}

The author declare that they have no conflict of interest.

\section{AUTHORS' CONTRIBUTIONS}

Lien Dang Phuoc Hai has done all works of the article as a sole author.

\section{REFERENCES}

1. Kitagawa Z. Doing Business in Japan. LexisNexis. 2017;p. 5-7.

2. Oda H. Japanese Law. Oxford: Oxford University Press 3ed. 2009;.
3. Frank G, r Bennett J. Getting Property Right: "Informal" Mortgages In The Japanese Courts. Pacific Rim Law \& Policy Journal Association. 2009;18(3).

4. Ono M. Unique Aspects of Japanese Securitization Relating to the Assignment of Financial Assets. Duke Journal of Comparative \& International Law. 2018;12.

5. Uchida T. Contract Law Reform in Japan and the UNIDROIT Principles. Uniform Law Review. 2011;16(3). Available from: https://doi.org/10.1093/ulr/16.3.705.

6. Ueno H. Japan: Civil Code reform and how it affects securitisation transactions in the Securitisation \& Structured Finance Handbook. Capital Markets Intelligence. 2018;.

7. Kanda H. Securitization in Japan. Duke Journal of Comparative \& International Law. 1998;8:359-380.

8. Ishikawa H. Codification, Decodification, and Recodification of the Japanese Civil Code, in the Scope and Structure of Civil Codes. Springer. 2013;Available from: https://doi.org/10.1007/ 978-94-007-7942-6_12.

9. Woo-Jung J. Cross-border Transfer and Collateralisation of Receivables - A Comparative Analysis of Multiple Legal Systems. Hart Publishing. 2018;.

10. Ueno H, Morita K. Practical Law Finance Global Guide 2019: Lending and taking security. Thomson Reuters. 2019;.

11. Giang BD. Establishing security measures based on assets in the Civil Code 2015 (Xác lập biện pháp bảo đảm bằng tài sản theo Bộ luật Dân sự 2015). Banking Review. 2016;18.

12. Dai DV. Law of Obligations and Security Obligation Performace Security: Judgments With Comments: Chapter 2 (Luật Nghĩa Vụ Và Bảo Đảm Thực Hiện Nghĩa Vụ Việt Nam: Bản Án Và Bình Luận Bản Án: Tập 2). Hong Duc Publisher. 2017;p. 872-886.

13. Woo-Jung J. The Assignment of Receivables under the Chinese Contract Law and Some Suggestions. Peking University Journal of Legal Studies. 2012;3:119.

14. Giang BD. Priority of A Secured Party In The Mortgage Over Debt Claims (Quyền Uuu Tiên Thanh Toán Của Bên Nhận Thế Chấp Quyền Đòi Nợ). Banking Review. 2012;17. 


\title{
Khía cạnh pháp lý trong bảo đảm thực hiện nghĩa vụ bằng khoản phải thu hình thành trong tương lai tại Nhật Bản và một số đề xuất cho Việt Nam
}

\author{
Liên Đăng Phước Hải*
}

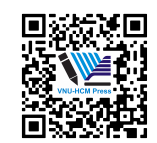

Use your smartphone to scan this QR code and download this article

Khoa Luât, Đai hoc Kinh tế - Luât, Đai học Quốc gia TP. Hồ Chí Minh, Việt Nam

Liên hệ

Liên Đăng Phước Hải, Khoa Luật, Đại học Kinh tế - Luật, Đại học Quốc gia TP. Hồ Chí Minh, Việt Nam

Email: haildp@uel.edu.vn

Lịch sử

- Ngày nhận: 25/8/2019

- Ngày chấp nhận: 10/12/2019

- Ngày đăng:11/9/2020

DOI : 10.32508/stdjelm.v4i3.633

\section{Check for updates}

\section{Bản quyền}

๑ ĐHQG Tp.HCM. Đây là bài báo công bố mở được phát hành theo các điều khoản của the Creative Commons Attribution 4.0 International license.

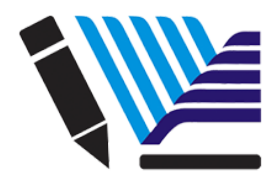

VNU-HCM Press

\section{TÓM TẮT}

Sử dụng tài sản bảo đảm là các khoản phải thu hình thành trong tương lai mang lại nhiều ý nghĩa về mặt kinh tế. Một mặt, hỗ trợ các doanh nghiệp và cá nhân có thể tiếp cận nguồn vốn một cách dễ dàng bằng những tài sản lưu động hình thành trong tương lai, mặt khác, khuyến khích hoạt động cho vay bằng cách giảm rủi ro nhờ vào tài sản bảo đảm. Tại Việt Nam, việc cho phép dùng tài sản là vật hình thành trong tương lai để bảo đảm thực hiện nghĩa vụ kể từ Bộ Luật Dân sự 2005 có tác động tích cực đến tài trợ vốn của doanh nghiệp. Tuy nhiên, thuật ngữ "vật hình thành trong tương lai" chưa thể bao quát các loại tài sản hình thành trong tương lai phổ biến khác, như các quyên tài sản hình thành trong tương lai. Thiếu sót này sau đó đã được khắc phục trong Nghị định 163/2006/NE-CP, sửa đổi, bổ sung bởi Nghị Định 11/2012/NE-CP (Nghị định 163). Theo Nghị định này, các bên có thể sử dụng các khoản phải thu hiện tại và hình thành trong tương lai để bảo đảm thực hiện nghĩa vụ. Bộ luật Dân sự 2005 được thay thế bằng Bộ luật Dân sự 2015, các quy định trong Nghị định 163 do đó cần thiết phải được đánh giá và thay đổi để phù hợp với Bộ luật Dân sư 2015 và thực tiễn. Chính phủ Viêt Nam đang lấy ý kiến về việc xây dưng Nghi đinh hướng dẫn về các biện pháp bảo đảm nghĩa vụ trong Bộ Luật Dân sự hiện hành đẹ̉ thay thế Nghị định 163. Bài viết hướng đến mục đích phân tích khung pháp lý trong Bộ luật Dân sự trước đây và hiện hành liên quan đến việc sử dụng các khoản phải thu hình thành trong tương lai để bảo đảm thực hiện nghĩa vụ, trong tương quan so sánh với pháp luật Nhật Bản. Từ đó, tác giả sẽ đưa ra các kiến nghị, rút ra từ kinh nghiệm lập pháp Nhật Bản, cho việc xây dựng pháp luật Việt Nam.

Từ khoá: quyền lợi được bảo đảm, khoản phải thu hình thành trong tương lai, tài sản bảo đảm, chuyển nhượng nhằm mục đích bảo đảm, hiệu lực, biện pháp bảo đảm
Trích dẫn bài báo này: Hải L D P. Khía cạnh pháp lý trong bảo đảm thực hiện nghĩa vụ bằng khoản phải thu hình thành trong tương lai tại Nhật Bản và một số đề xuất cho Việt Nam. Sci. Tech. Dev. J. Eco. Law Manag.; 4(2):872-880. 